\title{
Synthesis of hyperbranched polycarbonate by novel polymerization of di-tert-butyl tricarbonate with 1,1,1-tris(4-hydroxyphenyl)ethane
}

\author{
Makoto Miyasaka, Taichi Takazoe, Hiroto Kudo and Tadatomi Nishikubo \\ Hyperbranched polycarbonates (HBPCs) with $M_{\mathrm{n}}=2.1-7.1 \times 10^{3}$ were synthesized by $\mathrm{A}_{2}+\mathrm{B}_{3}$ polymerization using di-tert-butyl \\ tricarbonate as the $A_{2}$ monomer and 1,1,1-tris(4-hydroxyphenyl)ethane as the $B_{3}$ monomer. $A_{2}+B_{3}$ polymerization with different \\ feed ratios was achieved, controlling the degree of branching (DB) and the ratio of terminal functional groups. The DB of the \\ HBPCs is 0.5-0.7. The Boc-terminated PC was prepared by either a 1-pot or a 2-pot synthesis. In contrast, PC with terminal \\ phenol groups was prepared by deprotection of Boc-terminated PC.
}

Polymer Journal (2010) 42, 852-859; doi:10.1038/pj.2010.82; published online 15 September 2010

Keywords: di-tert-butyl tricarbonate; hyperbranched polymer; polycarbonate

\section{INTRODUCTION}

Polycarbonate (PC) with a Bisphenol A skeleton is one of the most widely used engineering plastics because it combines excellent physical, electrical and mechanical properties, including transparency, and heat-distortion resistance toughness. ${ }^{1,2}$ However, PC has a potential problem in both synthesis and processes. Two currently used commercial methods for the synthesis of PC are interfacial polycondensation of Bisphenol A with phosgene and transesterification of diphenyl carbonate with Bisphenol A. ${ }^{3}$ In recent years, there has been an increasing demand for a safe and environmentally friendly process to synthesize PC. ${ }^{4-9}$ PC has the disadvantage of having a high melt viscosity (low liquidity) and significant orientational birefringence caused by the Bisphenol-A backbone in the main chain. To solve these problems, there are a few applicable approaches, such as using relatively low molecular weight PC, introducing a different backbone into $\mathrm{PC}^{10}$ and making a polymer alloy or blends with additives that cancel the intrinsic birefringence of PC. ${ }^{1,2}$ These PCs have properties that are more suitable for applications. However, these modifications do not reduce the fundamental resolution of PC synthesis and its process.

In general, hyperbranched polymers are good candidates for overcoming the disadvantageous optical properties of PCs because of the fact that they possess low viscosity and high solvent solubility arising from their three-dimensional globular architecture with many branch structures. ${ }^{11-13}$ Hyperbranched polycarbonates (HBPCs) have been reported, ${ }^{14-18}$ but until now, only a few papers describing HBPCs derived from phenolic structures have been reported. ${ }^{19,20}$ Hyperbranched aryl PC from $\mathrm{AB}_{2}$ or $\mathrm{A}_{2} \mathrm{~B}$ condensation has been reported by Wooly et al. ${ }^{20}$ Compared with $\mathrm{AB}_{2}$ or $\mathrm{A}_{2} \mathrm{~B}$ approaches, monomers used for $\mathrm{A}_{2}+\mathrm{B}_{3}$ polymerization are easily prepared or purchased in cases in which the polymer structure can be controlled using different monomer structures. We recently developed an $\mathrm{A}_{2}+\mathrm{B}_{3}$ polymerization method for the synthesis of HBPC that uses the reaction between Bisphenol-A-bis(chloroformate) and 1,1,1-tris(4-hydroxyphenyl)ethane (THPE). ${ }^{21}$ This HBPC showed a lower birefringence change than the corresponding linear PC under a $1 \%$ drawn condition (T Nishikubo et al., unpublished data).

Herein, we describe a relatively easy synthesis of HBPC using di-tert-butyl tricarbonate (DBTC) instead of Bisphenol-A-bis(chloroformate) as a novel $\mathrm{A}_{2}$ monomer and THPE as a $\mathrm{B}_{3}$ monomer. HBPCs with both terminal Boc groups and phenol groups were easily prepared by a 1-pot synthesis and by treatment with acid of Boc-protected hyperbranched polymer, respectively.

\section{EXPERIMENTAL PROCEDURE}

Materials

Tetrahydrofuran (THF) (Wako Chemical, Osaka, Japan, 99\%) and pyridine (Kanto Chemical, Tokyo, Japan, 99.5\%) were distilled over sodium wire before use. Other materials were used without any purification.

\begin{abstract}
Measurements
${ }^{1} \mathrm{H}$ NMR spectra ( 500 and $600 \mathrm{MHz}$ ) were obtained using JEOL JNM-ECA-600 and JEOL JNM-ECA-500 spectrometers (JEOL, Tokyo, Japan) using chloroform- $d\left(\mathrm{CDCl}_{3}\right)$ or dimethylsulfoxide (DMSO)- $d_{6}\left(\left(\mathrm{CD}_{3}\right)_{2} \mathrm{SO}\right)$ as a solvent. The chemical shift references were as follows: chloroform- $h$, 7.26 p.p.m.; DMSO- $d_{5}, 2.50$ p.p.m.; $\left({ }^{13} \mathrm{C}\right) \mathrm{CDCl}_{3}, 77.0$ p.p.m. $\left(\mathrm{CDCl}_{3}\right)$; and DMSO- $d_{6}$, 39.5 p.p.m. (DMSO- $d_{6}$ ). Typical 1D FID was subjected to exponential multiplication with an exponent of $0.1 \mathrm{~Hz}\left(\right.$ for $\left.{ }^{1} \mathrm{H}\right)$ and $1.0-2.0 \mathrm{~Hz}$ (for ${ }^{13} \mathrm{C}$ ).
\end{abstract}


Fourier transform infrared spectra were obtained using a Nicolet Avatar 380 Fourier transform infrared instrument (Thermo Scientific K. K., Kanagawa, Japan). A few drops of the compound in $\mathrm{CH}_{2} \mathrm{Cl}_{2}$ or $\mathrm{CHCl}_{3}$ were applied to the surface of $\mathrm{KRS}$ or $\mathrm{KBr}$. After the solvent evaporated, the spectrum was acquired (128 scans, $4-\mathrm{cm}^{-1}$ resolution).

The number-average molecular weight $\left(M_{\mathrm{n}}\right)$ and molecular weight distribution (weight-average molecular weight/number-average molecular weight $\left.\left(M_{\mathrm{w}} / M_{\mathrm{n}}\right)\right)$ of the polymers were estimated on a TOSOH size exclusion chromatography system (HLC-8220; TOSOH, Tokyo, Japan) equipped with two consecutive polystyrene gel columns (TSK gels: SuperHZM-M $\times 2$; TOSOH), a refractive-index detector (RI-8022; TOSOH) and an ultraviolet detector (UV-8020; TOSOH) at $40^{\circ} \mathrm{C}$. The system was operated at a flow rate of $0.35 \mathrm{ml} \mathrm{min}^{-1}$ with THF as an eluent. The $M_{\mathrm{n}}$ and $M_{\mathrm{w}} / M_{\mathrm{n}}$ values of HBPC-OH were estimated on a TOSOH size exclusion chromatography system (HLC-8220; TOSOH) equipped with four consecutive polystyrene gel columns (Shodex gels: GF-1G 7B, GF310-HQ $\times 2$ and GF510-HQ; $\mathrm{TOSOH})$, a refractive-index detector (RI-8022; TOSOH) and an ultraviolet detector (UV-8020; TOSOH) at $40{ }^{\circ} \mathrm{C}$. The system was operated at a flow rate of $0.60 \mathrm{ml} \mathrm{min}^{-1}$ with a $N, N$-dimethyl formamide solution $(20 \mathrm{~mm}$ $\mathrm{LiBr}$ and $20 \mathrm{~mm}$ phosphoric acid) as an eluent. In these size exclusion chromatography (SEC) systems, polystyrene standards were used for calibration.

Differential scanning calorimetry: Glass transition temperature $\left(T_{\mathrm{g}}\right)$ was measured with an EXSTAR 6000/DSC6200 (SEIKO Instruments, Chiba, Japan) at a heating rate of $10{ }^{\circ} \mathrm{C} \mathrm{min}^{-1}$ under a nitrogen atmosphere (monitoring range: -30 to $220^{\circ} \mathrm{C}$ ).

Thermogravimetric analysis-differential thermal analysis (TG-DTA). Thermal decomposition temperature $\left(T_{\mathrm{d}}\right)$ was measured with an EXSTAR 6000/TG/ DTA6200 (SEIKO Instruments) at a heating rate of $10{ }^{\circ} \mathrm{C} \mathrm{min}^{-1}$ under a nitrogen atmosphere (monitoring range: $50-600^{\circ} \mathrm{C}$ ).

\section{Synthesis}

Synthesis of DBTC. DBTC was prepared with a 59\% yield according to a previously described method. ${ }^{22-24}$

Synthesis of linear PC. The mixture of DBTC $(131.1 \mathrm{mg}, 0.5 \mathrm{mmol})$ and $\left(\left(4,4^{\prime}-\alpha\right.\right.$-methylbenzylidene $)$ bisphenol $)(145.2 \mathrm{mg}, 0.5 \mathrm{mmol})$ in THF $(0.5 \mathrm{ml})$ was stirred at $30^{\circ} \mathrm{C}$ for $10 \mathrm{~h}$. Thereafter, pyridine $(42 \mu \mathrm{l}, \sim 1.05$ equivalent against DBTC) was added to the reaction mixture. The reaction mixture was poured into methanol/ $\mathrm{H}_{2} \mathrm{O}(7 / 3, \mathrm{v} / \mathrm{v})$ to precipitate the corresponding polymer. The precipitate was collected and dried under vacuum for $24 \mathrm{~h}$ yielding a white solid $(150.9 \mathrm{mg}, 91 \%) . \quad M_{\mathrm{n}}=3.3 \times 10^{3} \quad\left(M_{\mathrm{w}} / M_{\mathrm{n}}=1.78\right) .{ }^{1} \mathrm{H} \quad \mathrm{NMR}$ $\left(600 \mathrm{MHz}, \quad\right.$ DMSO- $\left.\mathrm{d}_{6}\right): \delta=9.318 \quad(\mathrm{~s}, \quad 1 \mathrm{H}$, terminal phenol), $7.38-7.15$ (m, 44 H, phenyl), 7.13-7.03 (m, 41 H, phenyl), 6.85-6.81 (m, $2 \mathrm{H}$, terminal phenyl), 6.70-6.65 (m, $2 \mathrm{H}$, terminal phenyl), $2.146\left(\mathrm{~s}, 16.8 \mathrm{H}, \mathrm{CH}_{3}\right), 2.073$ (s, $3.2 \mathrm{H}$, terminal $\left.\mathrm{CH}_{3}\right), 1.468(\mathrm{~s}, 7.1 \mathrm{H}, \mathrm{t}-\mathrm{Bu})$. Infrared (IR) (film, $\left.\mathrm{cm}^{-1}\right): 3450$ $\left(v_{\mathrm{O}-\mathrm{H}}\right), 2978,2871\left(v_{\mathrm{C}-\mathrm{H}}\right), 1775\left(v_{\mathrm{ArO}-(\mathrm{C}=\mathrm{O})-\mathrm{OAr}}\right)$.

Synthesis of $\mathrm{HBPC}-\mathrm{Boc}-\mathrm{OH}$. A typical procedure for the synthesis of HBPC (HBPC-Boc-OH) was as follows. The mixture of DBTC $(131.1 \mathrm{mg}, 500 \mu \mathrm{mol})$ and THPE $(102.1 \mathrm{mg}, 333 \mu \mathrm{mol})$ in THF $(1.0 \mathrm{ml})$ was stirred at $30^{\circ} \mathrm{C}$ for $2 \mathrm{~h}$. Thereafter, pyridine $(84 \mu \mathrm{l}, \sim 1.05$ equivalent against DBTC) was added to the reaction mixture. The reaction mixture was poured into methanol/ $\mathrm{H}_{2} \mathrm{O}(7 / 3$, $\mathrm{v} / \mathrm{v}$ ) to precipitate the corresponding polymer, and the precipitate was collected and dried under vacuum for $24 \mathrm{~h}$ to yield a white solid $(107 \mathrm{mg}, 82 \%)$. $M_{\mathrm{n}}=7.1 \times 10^{3} \quad\left(M_{\mathrm{w}} / M_{\mathrm{n}}=5.95\right) .{ }^{1} \mathrm{H} \quad \mathrm{NMR} \quad\left(600 \mathrm{MHz}, \quad\right.$ DMSO- $\left.d_{6}\right): \delta=9.355$ (br s, $0.38 \mathrm{H}$, phenol), $9.280(\mathrm{~m}, 0.57 \mathrm{H}$, phenol), $7.35-7.22(\mathrm{~m}, 4.86 \mathrm{H}$, phenyl), 7.19-7.04 (m, 4.86 H, phenyl), 6.87-6.77 (m, $1.16 \mathrm{H}$, phenyl), 6.73-6.63 (m, $1.16 \mathrm{H}$, phenyl), 2.152 (br s, $\left.1.50 \mathrm{H}, \mathrm{CH}_{3}\right), 2.090$ (br s, $1.20 \mathrm{H}$, $\mathrm{CH}_{3}$ ), 2.032 (br s, $0.30 \mathrm{H}, \mathrm{CH}_{3}$ ), 1.483 (s, $8.9 \mathrm{H}, t$-Bu). IR (film, $\left.\mathrm{cm}^{-1}\right): 3267$ $\left(v_{\mathrm{O}-\mathrm{H}}\right), 2980,2875\left(v_{\mathrm{C}-\mathrm{H}}\right), 1776\left(v_{\mathrm{ArO}-(\mathrm{C}=\mathrm{O})-\mathrm{OAr}}\right), 1759\left(v_{\mathrm{ArO}-(\mathrm{C}=\mathrm{O})-\mathrm{O}-t-\mathrm{Bu}}\right)$.

Instead of using methanol $/ \mathrm{H}_{2} \mathrm{O}(7 / 3, \mathrm{v} / \mathrm{v})$ solution for precipitation, pyridine $/ \mathrm{H}_{2} \mathrm{O}(1 / 3, \mathrm{v} / \mathrm{v})$ was applied. Similar results were obtained using this procedure.

Synthesis of Boc-protected HBPC (HBPC-Boc) by 2-stage reaction. HBPC-Boc$\mathrm{OH}\left(M_{\mathrm{n}}=4.0 \times 10^{3}, M_{\mathrm{w}} / M_{\mathrm{n}}=2.98\right)(105 \mathrm{mg})$ in THF/pyridine $(1.0 \mathrm{ml} / 113 \mu \mathrm{ml})$ was reacted with tert-butyldicarbonate (BDC) $(323 \mu \mathrm{l})$ at room temperature for $6 \mathrm{~h}$. The reaction mixture was poured into $n$-hexane to precipitate the corresponding polymer. The precipitate was collected and dried under vacuum for $24 \mathrm{~h}$ to yield a white solid $(110 \mathrm{mg}) . M_{\mathrm{n}}=6.2 \times 10^{3}\left(M_{\mathrm{w}} / M_{\mathrm{n}}=2.48\right) .{ }^{1} \mathrm{H} \mathrm{NMR}$ $\left(600 \mathrm{MHz}, \mathrm{DMSO}-d_{6}\right): \delta=7.31-7.08(\mathrm{~m}, 12 \mathrm{H}$, phenyl), 2.18-2.14 $(\mathrm{m}, 2.9 \mathrm{H}$, $\mathrm{CH}_{3}$ ), 1.48 (s, 10.8 H, $t$-Bu). IR (film, $\mathrm{cm}^{-1}$ ): 2981, 2937, $2874\left(v_{\mathrm{C}-\mathrm{H}}\right), 1776$ $\left(v_{\mathrm{O}-(\mathrm{C}=\mathrm{O})-\mathrm{O}}\right), 1759\left(v_{\mathrm{O}-(\mathrm{C}=\mathrm{O})-\mathrm{O}-t-\mathrm{Bu}}\right)$.

Synthesis of HBPC-Boc by 1 pot, 2 stage. The mixture of DBTC $(524.5 \mathrm{mg}$, $2.0 \mathrm{mmol})$ and THPE $(306.3 \mathrm{mg}, 1.0 \mathrm{mmol})$ in THF $(1.5 \mathrm{ml})$ was stirred at room temperature for $2 \mathrm{~h}$. Thereafter, pyridine $(1.0 \mathrm{ml})$ and BDC $(1.0 \mathrm{ml}$, $4.5 \mathrm{mmol}$ ) were added to the reaction mixture, and it was stirred at room temperature for another $6 \mathrm{~h}$. The reaction mixture was poured into $n$-hexane to precipitate the corresponding polymer, and the precipitate was collected and dried under vacuum for $24 \mathrm{~h}$ to yield a white solid $(415 \mathrm{mg}, 92 \%)$. $M_{\mathrm{n}}=4.3 \times 10^{3} \quad\left(M_{\mathrm{w}} / M_{\mathrm{n}}=2.8\right) . T_{\mathrm{g}}=119^{\circ} \mathrm{C} .{ }^{1} \mathrm{H}$ NMR $\left(600 \mathrm{MHz}\right.$, DMSO- $\left.d_{6}\right)$ : $\delta=7.33-7.08\left(\mathrm{~m}, 12 \mathrm{H}\right.$, phenyl), $2.18-2.14\left(\mathrm{~m}, 3 \mathrm{H}, \mathrm{CH}_{3}\right), 1.48(\mathrm{~s}, 12.5 \mathrm{H}$, $t$-Bu). IR $\left(\mathrm{cm}^{-1}\right)$ : 2981, 2937, $2874\left(v_{\mathrm{C}-\mathrm{H}}\right), 1776\left(v_{\mathrm{ArO}-(\mathrm{C}=\mathrm{O})-\mathrm{OAr}}\right), 1759$ $\left(v_{\mathrm{O}-(\mathrm{C}=\mathrm{O})-\mathrm{O}-t-\mathrm{Bu})}\right.$.

\section{Model compound synthesis and NMR study}

The compound 1,1,1-tris(4-tert-butoxycarbonyloxyphenyl)ethane (branching unit) was synthesized as described ${ }^{25}$ using less equivalent (2.2 equivalent against THPE, $306 \mathrm{mg}, 1 \mathrm{mmol}$ ) di-tert-butyl dicarbonate $(480 \mathrm{mg}, 2.2 \mathrm{mmol}$ ) to obtain mono and disubstituted compounds. Purification with column chromatography (silica, chloroform or chloroform/methanol=9:1) or PTLC (chloroform) resulted in three fractions: $\mathrm{F} 1,1,1,1$-tris(4-tert-butoxycarbonyloxyphenyl)ethane $\left(R_{\mathrm{f}}\right.$ (chloroform) $\left.=\sim 0.78\right)$; F2, 1-( $4^{\prime}$-hydroxyphenyl)-1,1-bis $(4-$ tert-butoxycarbonyloxyphenyl)ethane $\left(R_{\mathrm{f}}(\right.$ chloroform $/$ methanol $\left.=9: 1)=\sim 0.7\right)$; and F3, 1,1-bis-(4'-hydroxyphenyl)-1-(4-tert-butoxycarbonyloxyphenyl)ethane $\left(R_{\mathrm{f}}(\right.$ chloroform $/$ methanol=9:1) $=\sim 0.4)$.

1,1,1-Tris(4-tert-butoxycarbonyloxyphenyl)ethane (F1; branching unit): Yield $=14 \%$. ${ }^{1} \mathrm{H}$ NMR $\left(600 \mathrm{MHz}, \mathrm{CDCl}_{3}\right): \delta=7.080(\mathrm{~d}, J=9.0,6 \mathrm{H}$, phenyl), 7.051 (d, $J=9.0,6 \mathrm{H}$, phenyl), $2.130\left(\mathrm{~s}, 3.0 \mathrm{H}, \mathrm{CH}_{3}\right), 1.555(\mathrm{~s}, 27 \mathrm{H}, t-\mathrm{Bu}) .{ }^{1} \mathrm{H}$ NMR $\left(600 \mathrm{MHz}\right.$, DMSO- $\left.d_{6}\right): \delta=7.130$ (d, $J=7.2,6 \mathrm{H}$, phenyl), 7.077 (d, $J=7.2$, $6 \mathrm{H}$, phenyl), $2.132\left(\mathrm{~s}, 3.0 \mathrm{H}, \mathrm{CH}_{3}\right), 1.482\left(\mathrm{~s}, 27 \mathrm{H}, t\right.$-Bu) ${ }^{13} \mathrm{C}\left\{{ }^{1} \mathrm{H}\right\}$ NMR $\left(150 \mathrm{MHz}, \mathrm{CDCl}_{3}\right): \delta=$ aromatic region, $152.0,149.3,146.0,129.6,120.7$, aliphatic region, 83.6, 51.6, 30.9, 27.7. ${ }^{13} \mathrm{C}\left\{{ }^{1} \mathrm{H}\right\}$ NMR $\left(150 \mathrm{MHz}, \mathrm{DMSO}-d_{6}\right)$ : $\delta$ =aromatic region, $151.3,148.8,145.9,129.3,121.0$, aliphatic region, 83.2, $51.2,30.2,27.2$. Melting point $162-163^{\circ} \mathrm{C}$. IR $\left(\mathrm{cm}^{-1}\right): 2980,2935,2882\left(v_{\mathrm{C}-\mathrm{H}}\right)$, $1758\left(v_{\mathrm{O}-(\mathrm{C}=\mathrm{O})-\mathrm{O}-t-\mathrm{Bu})}\right.$.

1-(4'-Hydroxyphenyl)-1,1-bis(4-tert-butoxycarbonyloxyphenyl)ethane (F2; linear unit): Yield $=32 \% .{ }^{1} \mathrm{H}$ NMR $\left(600 \mathrm{MHz}, \mathrm{DMSO}-d_{6}\right): \delta=9.342(\mathrm{~s}, 1 \mathrm{H}$, $\mathrm{OH}), 7.097$ (d, $J=8.0,4 \mathrm{H}$, phenyl), 7.051 (d, $J=8.0,4 \mathrm{H}$, phenyl), 6.833 (d, $J=9.0,2 \mathrm{H}$, phenyl), 6.689 (d, $J=9.0,2 \mathrm{H}$, phenyl), $2.071\left(\mathrm{~s}, 3.0 \mathrm{H}, \mathrm{CH}_{3}\right)$, $1.481(\mathrm{~s}, 18 \mathrm{H}, t-\mathrm{Bu}) .{ }^{13} \mathrm{C}\left\{{ }^{1} \mathrm{H}\right\}$ NMR $\left(150 \mathrm{MHz}, \mathrm{DMSO}-d_{6}\right): \delta=$ aromatic region, $155.5,151.3,148.6,146.7,138.5,129.23,129.12,120.7,114.7$, aliphatic region, 83.1, 50.8, 30.3, 27.2. IR $\left(\mathrm{cm}^{-1}\right): 3447\left(v_{\mathrm{O}-\mathrm{H}}\right), 2981,2937\left(v_{\mathrm{C}-\mathrm{H}}\right), 1758$ $\left(v_{\mathrm{O}-(\mathrm{C}=\mathrm{O})-\mathrm{O}-t-\mathrm{Bu}}\right), 1734\left(v_{\mathrm{O}-(\mathrm{C}=\mathrm{O})-\mathrm{O}-t-\mathrm{Bu}}\right)$.

1,1-Bis-(4'-hydroxyphenyl)-1-(4-tert-butoxycarbonyloxyphenyl)ethane (F3; terminal unit): Yield $=11 \% .{ }^{1} \mathrm{H}$ NMR $\left(600 \mathrm{MHz}\right.$, DMSO- $\left.d_{6}\right): \delta=9.281$ (s, $2 \mathrm{H}, \mathrm{OH}), 7.061(\mathrm{~d}, J=9.0,2 \mathrm{H}$, phenyl), 7.026(d, $J=9.0,2 \mathrm{H}$, phenyl), 6.807 (d, $J=9.0,4 \mathrm{H}$, phenyl), 6.658 (d, $J=9.0,4 \mathrm{H}$, phenyl), $2.012(\mathrm{~s}, 3.0 \mathrm{H}$, $\left.\mathrm{CH}_{3}\right), 1.480(\mathrm{~s}, 9 \mathrm{H}, t-\mathrm{Bu}) .{ }^{13} \mathrm{C}\left\{{ }^{1} \mathrm{H}\right\} \mathrm{NMR}\left(150 \mathrm{MHz}, \mathrm{DMSO}-d_{6}\right): \delta=$ aromatic region, 155.3, 151.4, 148.4, 147.5, 139.3, 129.2, 129.1, 120.5, 114.5, aliphatic region, 83.1, 50.3, 30.4, 27.2. IR $\left(\mathrm{cm}^{-1}\right): 3409\left(v_{\mathrm{O}-\mathrm{H}}\right), 2981,2936,\left(v_{\mathrm{C}-\mathrm{H}}\right), 1757$ $\left(v_{\mathrm{O}-(\mathrm{C}=\mathrm{O})-\mathrm{O}-t-\mathrm{Bu}}\right), 1728\left(v_{\mathrm{O}-(\mathrm{C}=\mathrm{O})-\mathrm{O}-t-\mathrm{Bu}}\right)$.

Direct monitoring of the model reaction. The reaction between DBTC $(264 \mathrm{mg}, 1 \mathrm{mmol})$ and THPE $(102.1 \mathrm{mg}, 0.3 \mathrm{mmol})$ in THF- $d_{8}(0.75 \mathrm{ml})$ was followed by ${ }^{1} \mathrm{H}$ NMR spectroscopy.

Synthesis of HBPC-BDC. The mixture of DBTC $(813.2 \mathrm{mg}, 3.1 \mathrm{mmol})$ and THPE $(306.3 \mathrm{mg}, 1.0 \mathrm{mmol})$ in THF $(1.0 \mathrm{ml})$ was stirred at room temperature for $12 \mathrm{~h}$. The reaction mixture was poured into $n$-hexane to precipitate the corresponding polymer, and the precipitate was collected and dried under vacuum to yield a white solid $(573.7 \mathrm{mg}, 77 \%) . M_{\mathrm{n}}=1.7 \times 10^{3}\left(M_{\mathrm{w}} / M_{\mathrm{n}}=1.4\right)$. 
${ }^{1} \mathrm{H}$ NMR (600 MHz, $\left.\mathrm{CDCl}_{3}\right): \delta=7.20-7.08(\mathrm{~m}, 11.9 \mathrm{H}$, phenyl), 2.18-2.16 (m, $\left.3.0 \mathrm{H}, \mathrm{CH}_{3}\right), \quad 1.57(\mathrm{~s}, \quad 9.3 \mathrm{H}, t-\mathrm{Bu}) .{ }^{13} \mathrm{C}\left\{{ }^{1} \mathrm{H}\right\} \quad \mathrm{NMR}\left(150 \mathrm{MHz}, \mathrm{CDCl}_{3}\right)$ : $\delta=$ aromatic region, $149.30,149.28,148.86,148.84,147.57,146.7,146.6$, $146.2,145.6,129.82,129.80,129.73,129.71,120.40,120.37,120.4,120.21$, 120.20, aliphatic region, 86.6, 51.7, 30.8, 27.4. IR (film, $\left.\mathrm{cm}^{-1}\right)$ : 2982, 2840 $\left(v_{\mathrm{C}-\mathrm{H}}\right), 1832\left(v_{\mathrm{C}=\mathrm{O} \text {, carbonate }}\right), 1778\left(v_{\mathrm{C}=\mathrm{O} \text {, carbonate }}\right)$.

Synthesis of HBPC-Boc from the decomposition of the BDC group. HBPC-DBC $(0.3 \mathrm{~g})$ in THF $(1.5 \mathrm{ml})$ and pyridine $(10 \mu \mathrm{l}, 0.2 \mathrm{mmol})$ was stirred at room temperature for $12 \mathrm{~h}$. The reaction mixture was poured into $n$-hexane to precipitate the corresponding polymer, and the precipitate was collected and dried under vacuum for $24 \mathrm{~h}$ to yield a white solid $(253 \mathrm{mg}) . M_{\mathrm{n}}=1.4 \times 10^{3}$ $\left(M_{\mathrm{w}} / M_{\mathrm{n}}=1.4\right) .{ }^{1} \mathrm{H}$ NMR $\left(600 \mathrm{MHz}, \mathrm{CDCl}_{3}\right): \delta=7.16-7.08(\mathrm{~m}, 11.9 \mathrm{H}$, phenyl), 2.17-2.14 (m, $\left.3 \mathrm{H}, \mathrm{CH}_{3}\right), 1.48(\mathrm{~s}, 12.5 \mathrm{H}, t-\mathrm{Bu})$. IR $\left(\mathrm{cm}^{-1}\right): 2980,2934,2874$ $\left(v_{\mathrm{C}-\mathrm{H}}\right), 1758\left(v_{\mathrm{O}-(\mathrm{C}=\mathrm{O})-\mathrm{O}}\right), 1754\left(v_{\mathrm{O}-(\mathrm{C}=\mathrm{O})-\mathrm{O}-t-\mathrm{Bu}}\right)$.

Synthesis of HBPC-OH from the cleavage of the Boc group. HBPC-Boc-OH ( $\left.40.4 \mathrm{mg}, M_{\mathrm{n}}=5.9 \times 10^{3}, M_{\mathrm{w}} / M_{\mathrm{n}}=2.4\right)$ in THF $(1.0 \mathrm{ml})$ and $\mathrm{HCl}(100 \mu \mathrm{l}$, $\sim 1 \mathrm{mmol}$ ) was stirred under reflux for $3 \mathrm{~h}$. The usual aqueous extraction with ethyl acetate yielded crude viscous oil as a product. The resulting oil was dissolved in ethyl acetate and then poured into $n$-hexane to precipitate the corresponding polymer. The precipitate was collected and dried under vacuum for $24 \mathrm{~h}$ to yield a white solid $(37.5 \mathrm{mg}) . M_{\mathrm{n}}=2.9 \times 10^{3}\left(M_{\mathrm{w}} / M_{\mathrm{n}}=3.0\right.$, from SEC (eluent/THF)). $T_{\mathrm{g}}=188^{\circ} \mathrm{C} .{ }^{1} \mathrm{H}$ NMR $\left(600 \mathrm{MHz}, \mathrm{DMSO}-d_{6}\right): \delta=9.355(\mathrm{~s}, 1.0 \mathrm{H}$, phenol), 9.280 (s, $1.11 \mathrm{H}$, phenol), 7.35-7.20 (m, 7.94 H, phenyl), 7.18-7.05 (m, $7.84 \mathrm{H}$, phenyl), 6.87-6.76 ( $\mathrm{m}, 4.36 \mathrm{H}$, phenyl), 6.72-6.63 ( $\mathrm{m}, 4.31 \mathrm{H}$, phenyl), 2.177 (br s, $1.33 \mathrm{H}$, branching unit $\mathrm{CH}_{3}$ ), $2.100\left(\right.$ br s, $2.84 \mathrm{H}$, linear unit $\mathrm{CH}_{3}$ ), 2.025 (br s, $1.86 \mathrm{H}$, terminal unit $\left.\mathrm{CH}_{3}\right)$. IR $\left(\mathrm{cm}^{-1}\right): 3267\left(v_{\mathrm{O}-\mathrm{H}}\right), 2980,2875$ $\left(v_{\mathrm{C}-\mathrm{H}}\right), 1776\left(v_{\mathrm{O}-(\mathrm{C}=\mathrm{O})-\mathrm{O})}\right.$.

\section{RESULTS AND DISCUSSION}

\section{Synthesis of LPC}

First, we applied the procedure to the synthesis of linear PC (LPC) (Scheme 1). The reaction between DBTC and $\left(\left(4,4^{\prime}-\alpha\right.\right.$-methylbenzylidene)bisphenol) was carried out at $30^{\circ} \mathrm{C}$ for $2-10 \mathrm{~h}$. The reaction proceeded smoothly, even at around room temperature, to yield the corresponding LPC with $M_{\mathrm{n}}=1.4-3.3 \times 10^{3}$ and $M_{\mathrm{w}} / M_{\mathrm{n}}=1.5-1.8$ in $82-90 \%$ yield. The IR spectrum of this LPC showed characteristic absorptions assigned to phenol $\left(v_{\mathrm{O}-\mathrm{H}}=3450 \mathrm{~cm}^{-1}\right)$ and carbonyl $\left(v_{\mathrm{C}=\mathrm{O}}=1775 \mathrm{~cm}^{-1}\right)$ groups. ${ }^{1} \mathrm{H}$ NMR in DMSO- $d_{6}$ also showed phenol and terminal tert-butyl protons at 9.318 and 1.468 p.p.m., respectively.

\section{Synthesis of HBPC-Boc-OH}

The reaction of DBTC and THPE was performed in THF at $30^{\circ} \mathrm{C}$ in certain feed ratios. The reaction was quenched with pyridine. The products were then precipitated in methanol $/ \mathrm{H}_{2} \mathrm{O}$ to yield the corresponding $\mathrm{HBPC}$ (Scheme 2) at $\sim 80 \%$. The conditions and results are summarized in Table 1 . All of these obtained polymers are soluble in common organic solvents.

When the feed ratio of DBTC/THPE was 1.5, HBPC-Boc-OH with the highest $M_{\mathrm{n}}\left(7.1 \times 10^{3}\right)$ and relatively broad $M_{\mathrm{w}} / M_{\mathrm{n}}(=6.0)$ was

\section{Table 1 Synthesis of hyperbranched polycarbonate ${ }^{a}$}

\begin{tabular}{lcccccc}
\hline Run & DBTC/THPE & Yield $(\%)^{\mathrm{c}}$ & $M_{n}{ }^{\mathrm{d}}$ & $M_{w} / M_{n}$ & Boc/phenol $^{\mathrm{e}}$ & $D^{\mathrm{f}}$ \\
\hline 1 & 1.0 & 36 & 2100 & 1.26 & 6.4 & 0.52 \\
2 & 1.0 & 63 & 4000 & 2.98 & 2.3 & 0.55 \\
3 & 1.0 & 45 & 5900 & 2.39 & 1.6 & 0.54 \\
4 & 1.5 & 37 & 1200 & 1.27 & 19.0 & 0.56 \\
5 & 1.5 & 77 & 5000 & 2.93 & 9.7 & 0.59 \\
6 & 1.5 & 82 & 7100 & 5.95 & 9.21 & 0.60 \\
7 & 2.0 & 84 & 5500 & 3.71 & 34.1 & 0.76 \\
$8^{\mathrm{g}}$ & 2.0 & 84 & 4600 & 3.04 & 34.8 & 0.78
\end{tabular}

Abbreviations: DB, degree of branching; DBTC, di-tert-butyl tricarbonate; THPE, 1,1,1-tris(4hydroxyphenyl)ethane.

aRuns $1,6,7$ and 8 ; the reaction was carried out at $30^{\circ} \mathrm{C}$ for $2 \mathrm{~h}$. Runs 4 and 5 were carried out at $30^{\circ} \mathrm{C}$ for 0.5 and $1 \mathrm{~h}$, respectively. Runs 2 and 3 were carried out at room temperature for 4 and $6.5 \mathrm{~h}$, respectively.

${ }^{\mathrm{b}}$ Feed ratio.

cInsoluble fraction in methanol/ $\mathrm{H}_{2} \mathrm{O}(=7: 3(\mathrm{v} / \mathrm{v}))$.

dEstimated by size exclusion chromatography (eluent/tetrahydrofuran) based on polystyrene standards.

${ }^{\mathrm{e}}$ Calculated from ${ }^{1} \mathrm{H}$ NMR.

fDB was estimated from ${ }^{1} \mathrm{H}$ NMR.

gThe reaction was examined by three times larger scale.
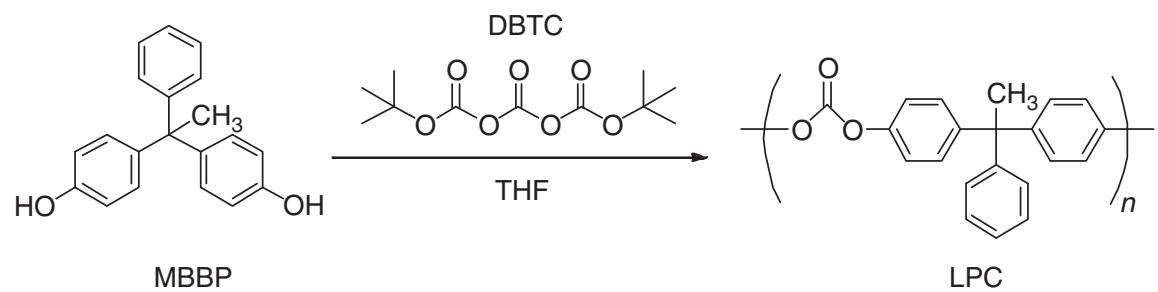

Scheme 1 Synthesis of linear polycarbonate.

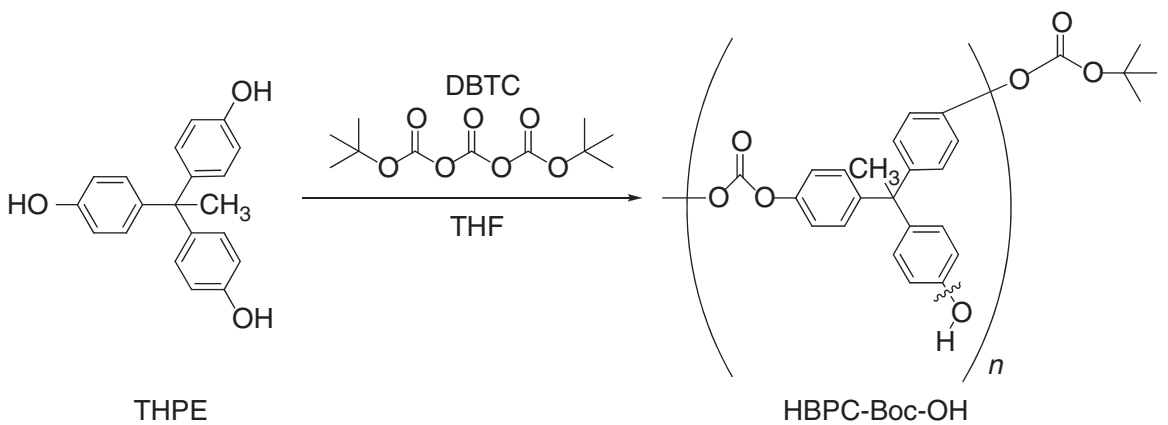

Scheme 2 Synthesis of hyperbranched polycarbonates. 


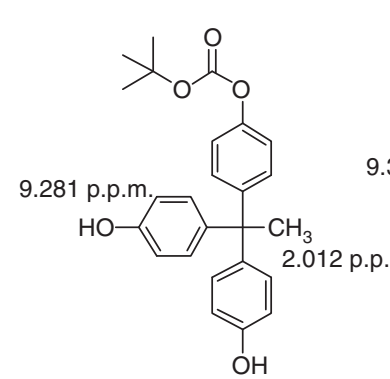

Terminal Unit

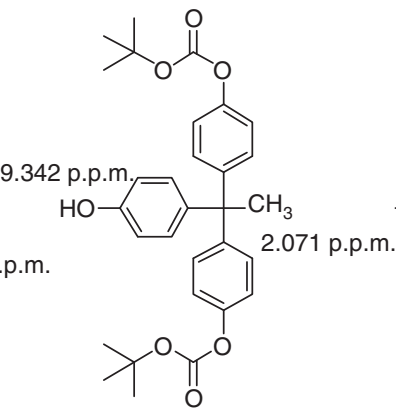

Linear Unit

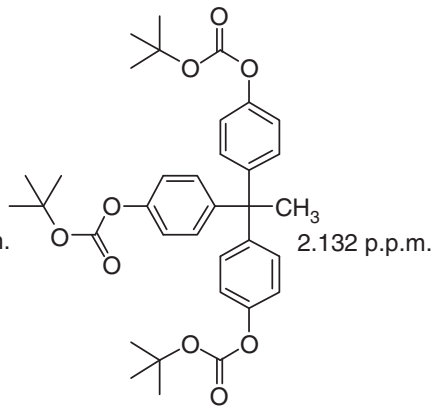

Branching Unit

Scheme 3 Three model compounds (chemical shift in dimethylsulfoxide- $d_{6}$ ).

a

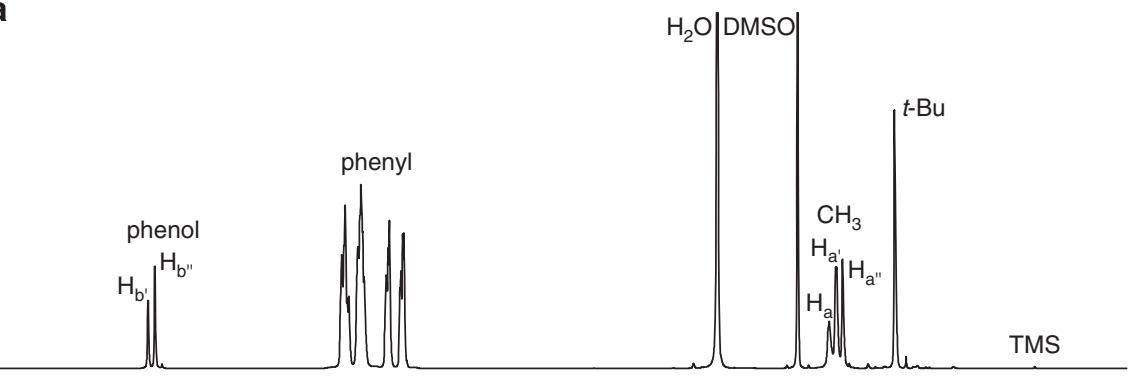

b

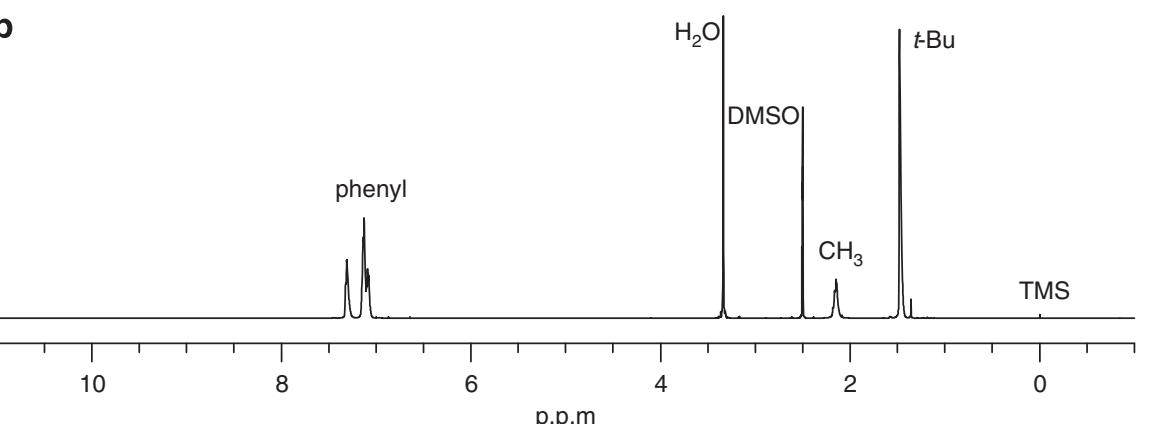

Figure $1^{1} \mathrm{H}$ NMR spectra $\left(600 \mathrm{MHz}\right.$, dimethylsulfoxide (DMSO)- $d_{6}$ ) (a) of hyperbranched polycarbonate (HBPC)-Boc-OH (from Run 2 in Table 1 ) and (b) after introduction of Boc to form HBPC-Boc. The subscript of $a, a^{\prime}\left(b^{\prime}\right)$ and $a^{\prime \prime}\left(b^{\prime \prime}\right)$ in Figure la was assigned to branching, linear and terminal units, respectively.

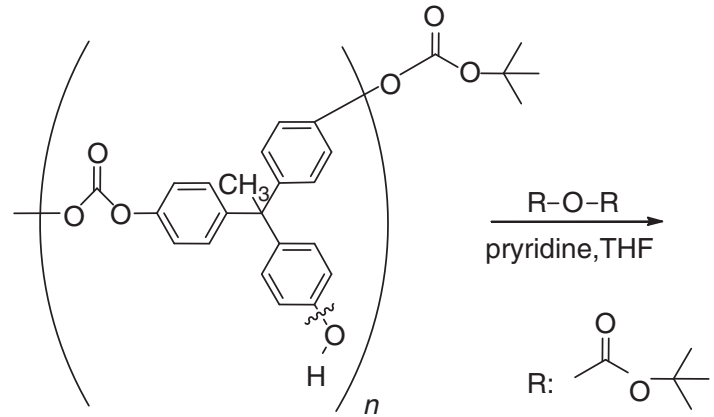

HBPC-Boc-OH

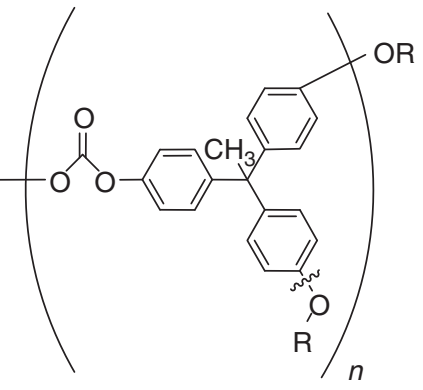

HBPC-Boc

Scheme 4 Synthesis of hyperbranched polycarbonate (HBPC)-Boc.

obtained (Run 6 in Table 1). When a shorter reaction time was used in this polymerization (Runs 4 and 5 in Table 1), the yield, $M_{\mathrm{n}}$ and $M_{\mathrm{w}} / M_{\mathrm{n}}$ were decreased. On the other hand, the longer reaction gave a significant amount of gel product. When the feed ratio of DBTC/ THPE was increased to 2, the corresponding HBPC-Boc-OH had significant amounts of the Boc group on the terminus. The terminal ratio of Boc and phenol groups in this polymerization increased with the feed ratio of DBTC, except in the case of a short reaction time (Run 4 in Table 1). In this polymerization, the terminus of the HBPC consisted of both Boc and phenol groups. 

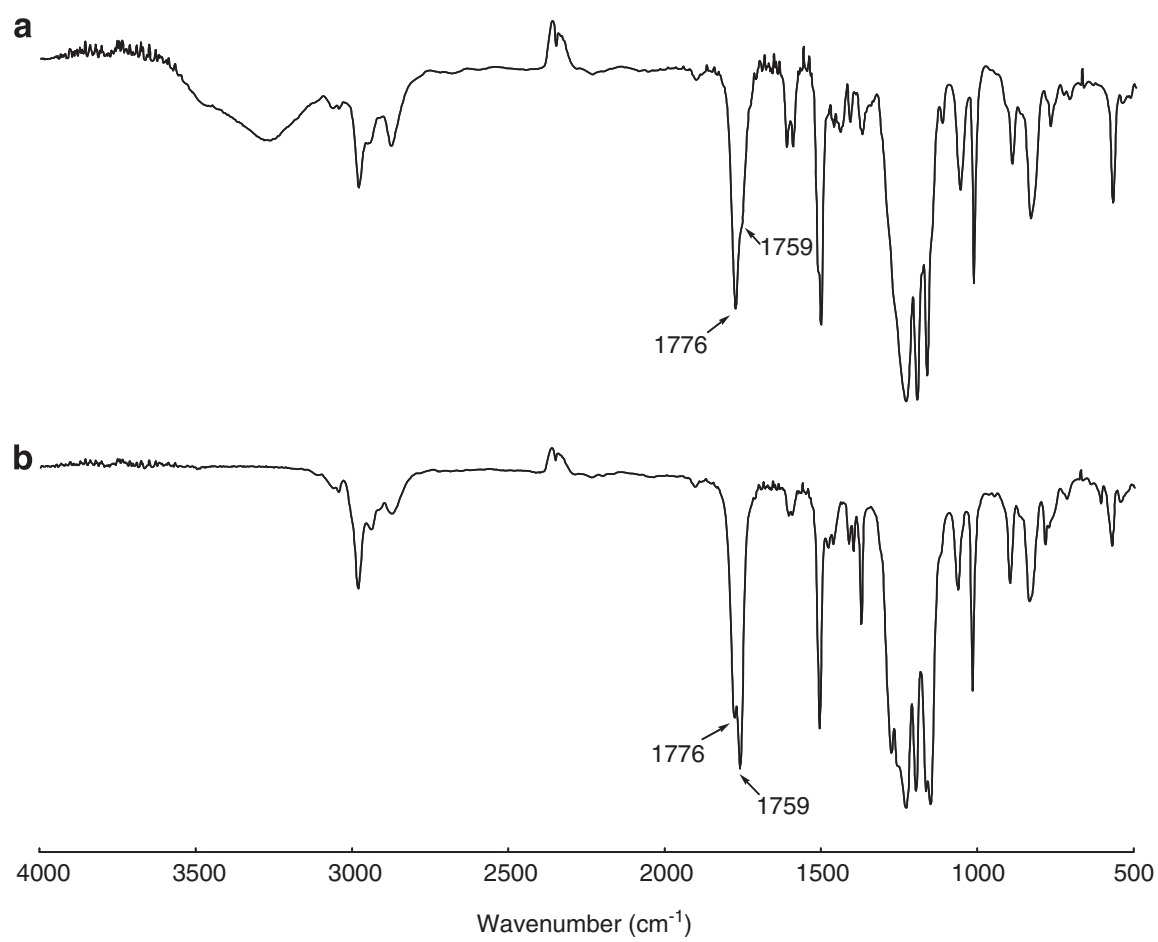

Figure 2 Infrared spectra of (a) hyperbranched polycarbonate (HBPC)-Boc-OH (from Run 2 in Table 1) and (b) HBPC-Boc.

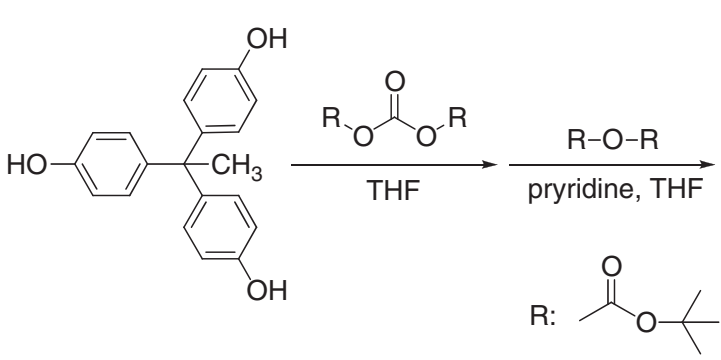

THPE

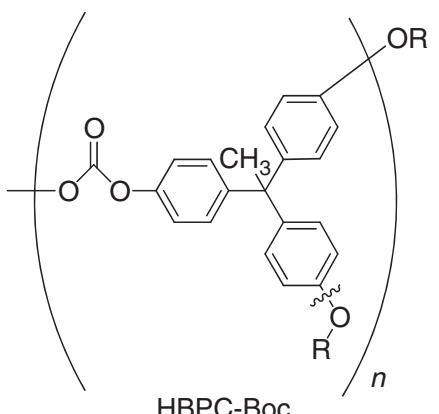

HBPC-Boc

Scheme 5 Synthesis of hyperbranched polycarbonate (HBPC)-Boc by 1 pot, 2 stage.

The degree of branching (DB) was determined by an ${ }^{1} \mathrm{H}$ NMR spectrum by three different ${ }^{1} \mathrm{H}$ NMR chemical shifts for the three different methyl groups and two different phenolic protons. A detailed investigation of the $\mathrm{DB}$ of hyperbranched aryl $\mathrm{PC}$, from $\mathrm{AB}_{2}$ or $\mathrm{A}_{2} \mathrm{~B}$ condensation, was reported by Wooly et al. ${ }^{20}$ To confirm methyl and phenolic protons, which were assigned from linear, branching and chain end units, we studied and evaluated DB using a model compound prepared from the reaction between DBTC and THPE. The reaction progress was followed up by direct monitoring using ${ }^{1} \mathrm{H}$ NMR spectroscopy in THF- $d_{8}$. The reaction of DBTC and THPE yields three different products, mono (terminal), di (linear) and trisubstituted (branching) structures (Scheme 3), showing an ${ }^{1} \mathrm{H}$ NMR spectrum with three singlets around 8 p.p.m. assigned to the phenol group and with four singlets around 2 p.p.m. assigned to the methyl group in the early stage. According to the integration value, the compounds showed the characteristic resonance for methyl protons at 2.179, 2.116 and 2.057 p.p.m. for branching, linear and terminal units, respectively, whereas linear and terminal units also had distinct phenolic protons at 9.290 and 9.193 , respectively. The methyl and phenolic chemical shifts were shifted downfield according to the substitution number.

Each model compound (Scheme 3), which was synthesized separately, was also investigated by ${ }^{1} \mathrm{H}$ NMR in DMSO- $d_{6}$ and showed a similar resonance for the methyl protons at 2.132, 2.071 and 2.012 p.p.m. for branching, linear and terminal units, respectively. Notably, the resonances were very similar to the corresponding HBPC and were 2.152, 2.090 and 2.032 p.p.m. for branching, linear and terminal units, respectively (see Figure 1a). This result allows us to estimate DB using ${ }^{1} \mathrm{H}$ NMR in the following Equation ${ }^{26}$

$$
\mathrm{DB}=\frac{\text { branching units+terminal units }}{\text { branching units+terminal units+linear units }}
$$

Using ${ }^{1} \mathrm{H}$ NMR analysis, a DB of $0.5-0.6$ was calculated for the HBPC. DB was clearly correlated with the feed ratio of monomers (see Table 1). In other words, the extent of branching increases when the ratio of DTBC increases. This may be explained as follows: the higher feed ratio of DTBC amplifies the formation of branching units. 
a

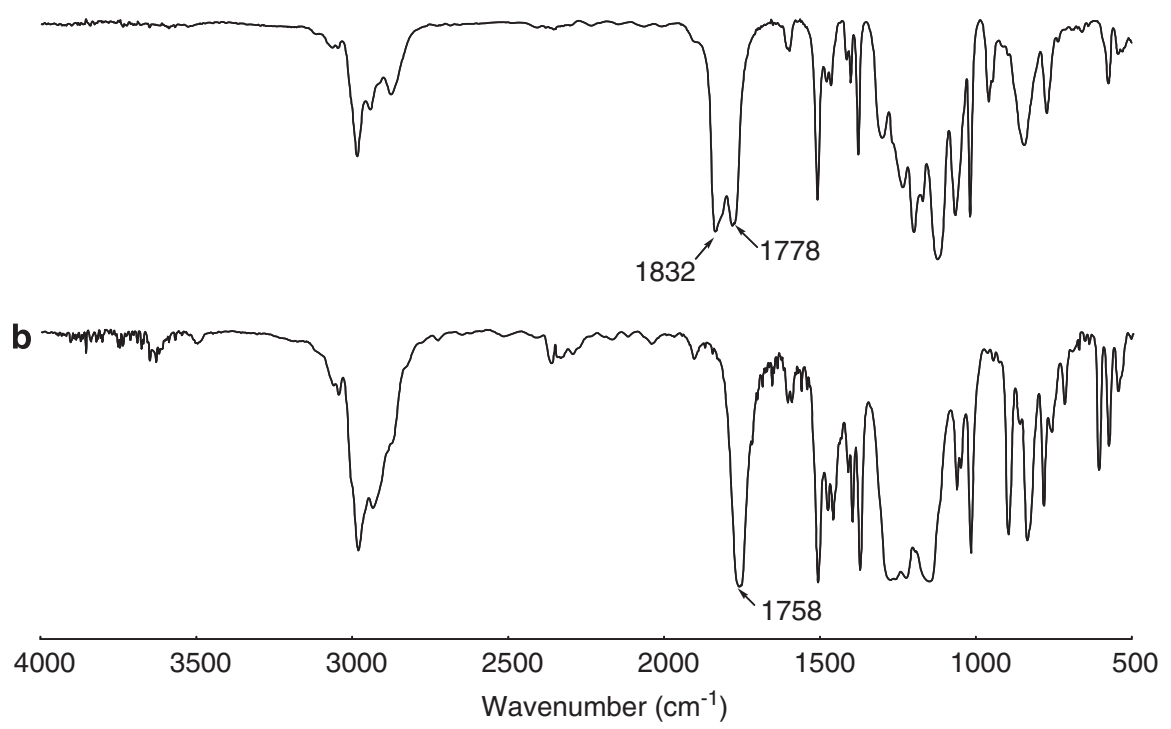

Figure 3 Infrared spectra of (a) hyperbranched polycarbonate (HBPC)-tert-butyldicarbonate (BDC) and (b) HBPC-Boc from the decomposition of HBPC-BDC.

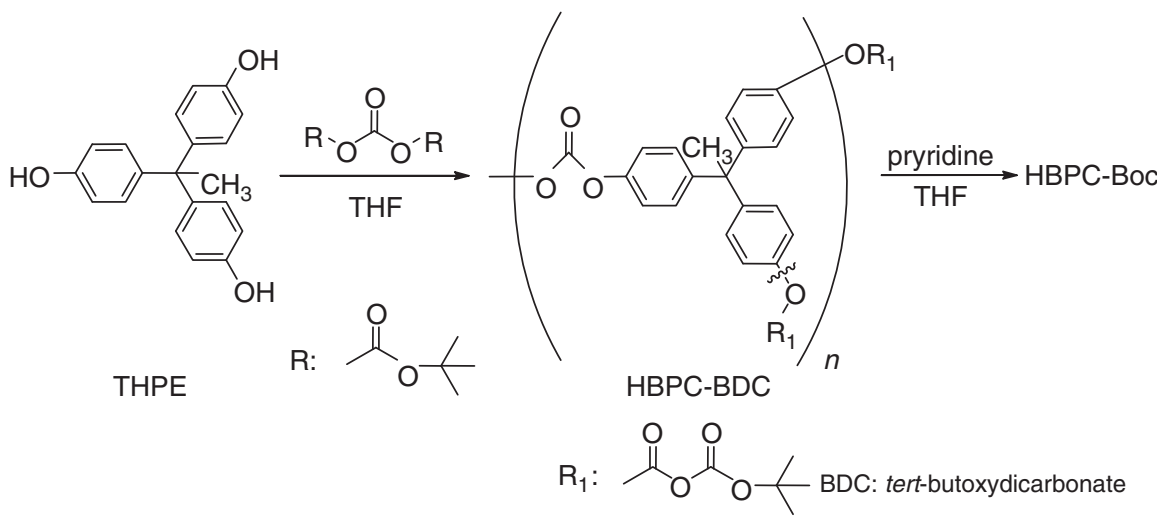

Scheme 6 Synthesis of hyperbranched polycarbonate (HBPC)-Boc from the decomposition of HBPC-tert-butyldicarbonate (BDC).

Synthesis of HBPC-Boc by a 2-stage reaction

HBPC-Boc-OH $\left(M_{\mathrm{n}}=4.0 \times 10^{3}, \mathrm{DB}=0.55\right.$, Run 2 in Table 1) was subjected to a reaction with (Boc) $)_{2} \mathrm{O}$ to obtain HBPC-Boc (Scheme 4). The characteristic absorption of IR and ${ }^{1} \mathrm{H}$ NMR that is ascribed to phenolic protons disappeared completely, and the ${ }^{1} \mathrm{H}$ NMR spectrum showed a unique unresolved singlet (multiplet) around 2.4 p.p.m. that was ascribed to a methyl proton (Figure 1b). In the IR spectra, by increasing the contents of the Boc group, the carbonyl vibration $\left(v_{\mathrm{C}=\mathrm{O}}\right)$ at $1759 \mathrm{~cm}^{-1}$ became more intense than that at $1776 \mathrm{~cm}^{-1}$ (Figure 2). These absorptions at 1759 and $1776 \mathrm{~cm}^{-1}$ were assigned to tert-butoxycarbonyl and diphenyl carbonate, respectively, which is supported by the other IR spectra of HBPC-Boc-OH with a different feed ratio. A shift of the SEC profile toward a higher molecular weight range $\left(M_{n}=6.2 \times 10^{3}\right)$ was observed after the introduction of a Boc group at the terminal. The shape of the profile was the same as that of the precursor's. However, the molecular weight distribution of the obtained polymer $\left(M_{\mathrm{w}} / M_{\mathrm{n}}=2.48\right)$ was narrow compared with that of the initial polymer $\left(M_{\mathrm{w}} / M_{\mathrm{n}}=2.98\right)$, which indicates that the solubility of HBPC-Boc in $n$-hexane seems to be better than that for HBPC-Boc-OH.
Synthesis of HBPC-Boc by 1 pot, 2 stage

Another simple approach for the synthesis of HBPC-Boc was also examined using direct addition of $(\mathrm{Boc})_{2} \mathrm{O}$ into the reaction mixture after a certain time (1 pot, 2 stage in Scheme 5 ). No phenolic protons were observed in the ${ }^{1} \mathrm{H}$ NMR and IR spectra, both of which were coincident with the HBPC-Boc obtained in the previous section.

Synthesis of HBPC-Boc from the decomposition of a BDC group During the investigation of HBPC-Boc synthesis, we found that an excess of DBTC, without pyridine quenching, produces the corresponding polymer after precipitation from $n$-hexane. The IR spectrum was significantly different for HBPC-Boc-OH. Two distinctly different carbonyl absorptions at 1832 and $1778 \mathrm{~cm}^{-1}$ (Figure 3a) were seen. These unique split absorptions have been observed in carboxylic anhydride. The ${ }^{13} \mathrm{C}$ NMR spectrum between 145 and 150 p.p.m. also produced more resonances than the corresponding HBPC-Boc. From this evidence, we concluded that the polymer obtained from this preparation was protected with the BDC group. Additional reaction of HBPC-BDC with pyridine in THF and precipitation from THF to $n$-hexane yielded the corresponding HBPC-Boc (Scheme 6). 
The characteristic absorption at $1832 \mathrm{~cm}^{-1}$ in the IR spectrum disappeared, and the exact same spectrum with HBPC-Boc was observed (Figure $3 \mathrm{~b}$ ). This indicates that this polymerization system always included the BDC group as an intermediate. Judging from these results, a relatively high ratio of Boc and phenol in a short polymerization (Run 4 in Table 1) was associated with the formation of a significant amount of oligomeric BDC in the early stages.

\section{Thermal properties of HBPC derivatives}

Thermal decomposition temperature $\left(T_{\mathrm{d}}\right)$ was measured by Thermogravimetric analysis-differential thermal analysis. A higher initial decomposition temperature and a larger weight loss were observed with increasing Boc content (Boc content increased from (b) to (e)). Notably, the thermal weight loss was in good agreement with the calculated Boc content in HBPC. The preliminary thermal deprotection reaction was examined in the film state (sample was the same as in Figure 4c) on $\mathrm{KBr}$ using a heating stage. This reaction progress was monitored by Fourier transform infrared. On heating at $110^{\circ} \mathrm{C}$ for $0.5 \mathrm{~h}$, the absorption areas of the phenol and tert-butyl groups decreased initially $(<2 \mathrm{~min})$. In contrast, the absorption of diphenyl carbonate $\left(v_{\mathrm{C}=\mathrm{O}}=1776 \mathrm{~cm}^{-1}\right)$ increased, which indicates that the Boc and phenol groups reacted when they were heated to form diphenyl carbonate. However, no further progress was observed under the same temperature conditions. After changing the temperature from 110 to $160^{\circ} \mathrm{C}$, all absorptions dramatically changed; that is, the tert-butyl

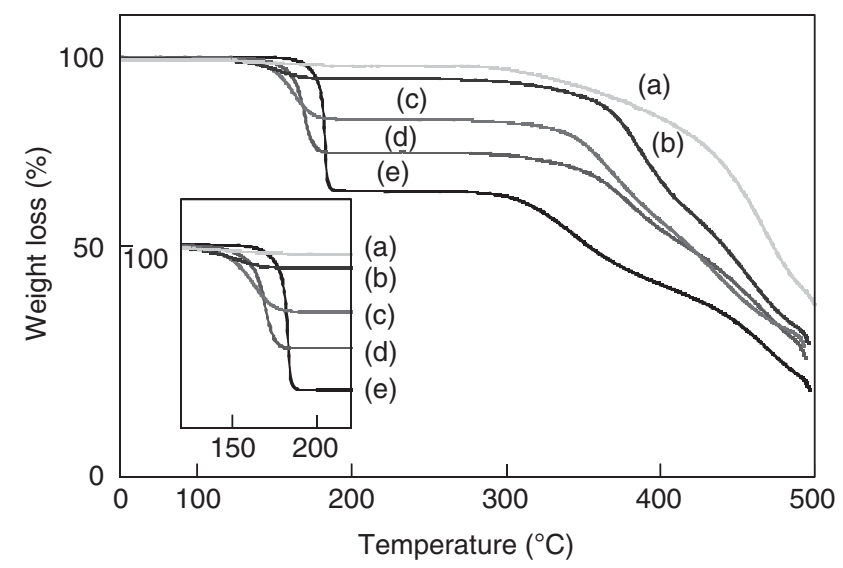

Figure 4 Thermogravimetric analysis profiles of hyperbranched polycarbonate (HBPC) derivatives: (a) HBPC-OH, (b) Run 2, (c) Run 6, (d) Run 7 in Table 1, and (e) HBPC-Boc (from 1 pot, 2 stage). Inset: expansion between 120 and $220^{\circ} \mathrm{C}$. and tert-butoxycarbonyl groups significantly decreased. In contrast, thermal deprotection produced a phenol group that corresponded to increasing phenol absorption. The thermal stability of $\mathrm{HBPC}-\mathrm{OH}$ was located just above curve (b) in Figure 4 and showed the good agreement we described above.

\section{Synthesis of HBPC-OH}

HBPC-Boc-OH $\left(M_{\mathrm{n}}=5.9 \times 10^{3}, M_{\mathrm{w}} / M_{\mathrm{n}}=2.39, \mathrm{DB}=0.54\right.$, Run 3 in Table 1) was reacted with $\mathrm{HCl} / \mathrm{THF}$ at room temperature or under reflux conditions for $3 \mathrm{~h}$ to obtain an HBPC with terminal phenol groups (Scheme 7). After precipitation from $n$-hexane, a significant decrease of $t$-Bu groups was observed in ${ }^{1} \mathrm{H}$ NMR, which almost disappeared under reflux conditions. The IR spectrum also gave a weaker absorption at $1758 \mathrm{~cm}^{-1}$ (shoulder) associated with the tertbutoxycarbonyl group. The main absorption at $1776 \mathrm{~cm}^{-1}$ was only observed after Boc deprotection. However, the SEC profile of HBPC$\mathrm{OH}$ in THF shifted to the lower molecular side $\left(M_{\mathrm{n}}=2.9 \times 10^{3}\right.$, $\left.M_{\mathrm{w}} / M_{\mathrm{n}}=3.02, \mathrm{DB}=0.53\right)$. The polarity of the polymer increased because of the deprotection of Boc, compared with the partially protected HBPC-Boc-OH. This polarity change might affect the elution time. In the case of SEC (dimethyl formamide), $M_{\mathrm{n}}$ values of HBPC-Boc-OH and HBPC-OH were $1.5 \times 10^{4}\left(M_{\mathrm{w}} / M_{\mathrm{n}}=3.32\right)$ and $1.3 \times 10^{4}\left(M_{\mathrm{w}} / M_{\mathrm{n}}=2.70\right)$, respectively. Even though the low molecular fraction increased slightly, the SEC profiles from dimethyl formamide did not change dramatically compared with the SEC from THF. The $T_{\mathrm{g}}$ of HBPC-OH was around $188^{\circ} \mathrm{C}$, which is lower than that previously reported ${ }^{19}\left(T_{\mathrm{g}}=205^{\circ} \mathrm{C}\right)$ because of lower molecular weight. However, in comparison with HBPC-Boc $\left(T_{\mathrm{g}}=119^{\circ} \mathrm{C}\right)$, the $T_{\mathrm{g}}$ was significantly higher because of an increase in the number of phenol groups. These results indicate that the deprotection of Boc occurred smoothly and yielded the corresponding HBPC-OH. In contrast, HBPC-Boc-OH exhibited no $T_{\mathrm{g}}$ in the first scan. However, subsequent measurements showed $T_{\mathrm{g}}$ as an endothermic peak around $185^{\circ} \mathrm{C}$. This $T_{\mathrm{g}}$ was similar to the one for $\mathrm{HBPC}-\mathrm{OH}$, giving more evidence that thermal deprotection forms the corresponding $\mathrm{HBPC}-\mathrm{OH}$ under heating.

\section{Conclusion}

In this study, we demonstrated easy synthesis of linear and HPBC using DBTC as the $\mathrm{A}_{2}$ monomer and revealed that DB could be controlled simply by changing the feed ratio. We obtained terminal functionalized HBPC with Boc and phenol using 1-pot and 2-pot syntheses. We also observed that polymerization progressed with tert-butyl dicarbonate as an intermediate functional group; it was then transferred to the Boc and phenol groups during reaction

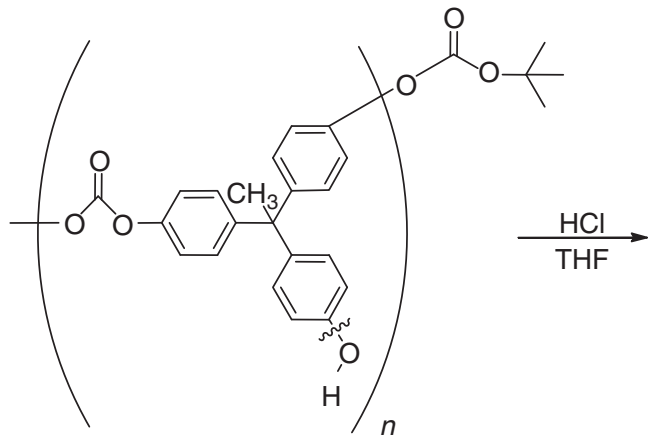

$\mathrm{HBPC}-\mathrm{Boc}-\mathrm{OH}$

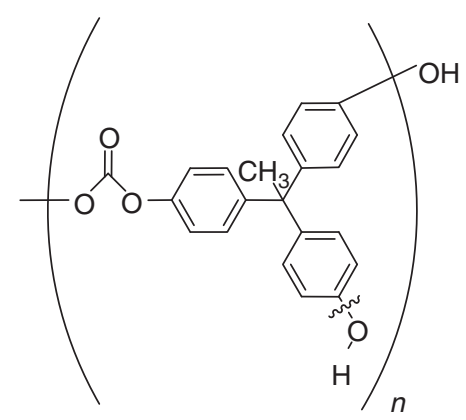

$\mathrm{HBPC}-\mathrm{OH}$

Scheme 7 Synthesis of hyperbranched polycarbonate (HBPC)-OH. 
quenching or precipitation. In this regard, it is suggested that we are able to introduce other substituents easily using an electrophile in the second stage of this polymerization. The investigations of mechanical and optical properties of HBPCs, especially birefringence, are now in progress. This HBPC-Boc could be useful for high performance $\mathrm{KrF}$ resist in the near future.

1 Freitag, D., Grica, U., Muller, P. R. \& Nourvertne, W. in Encyclopedia of Polymer Science and Engineering (eds Mark, H. F., et al.) Vol. 11, 648-718 (Wiley, New York, 1987).

2 Freitag, D., Fengler, D. \& Morbitzer, L. Routes to new aromatic polycarbonated with special material properties. Angew. Chem. Int. Ed. Eng. 30, 1598 (1991).

3 Clagett, D. C. \& Shafer, S. J. in Comprehensive Polymer Science (eds. Allen, G., Bevington, J. C.) Vol. 5, 345-356 (Pergamon Press, Oxford, 1989).

4 Ono, Y. Dimethyl carbonate for environmentally benign reaction. Pure Appl. Chem. 68, 367 (1996)

5 Kim, W. B., Joshi, U. A. \& Lee, J. S. Making polycarbpnates without employing phosgene: an overview on catalytic chemistry of intermidediate and precursor syntheses for polycarbonate. Ind. Eng. Chem. Res. 43, 1897 (2004).

$6 \mathrm{Kim}$, W. B. \& Lee, J. S. Comparison of polycarbonate precursors synthesized from catalytic reactions of bisphenol-A with diphenyl carbonate, dimethyl carbonate, or carbon monoxide. J. Appl. Polym. Sci. 86, 937 (2002).

7 Ishii, H., Goyal, M., Ueda, M., Takeuchi, K. \& Asai, M. Direct synthesis of polycarbonate from carbon monoxide and Bisphenol A using efficient Pd complex catalyst system. Macromol. Rapid Commun. 22, 376 (2001).

8 Haba, O., Itakura, I., Ueda, M. \& Kuze, S. Synthesis of polycarbonate from dimethyl carbonate and Bisphenol-A through a non-phosgene process. J. Polym. Sci. Part A Polym. Chem. 37, 2087 (1999).

9 Yahiro, T., Matsushima, K., Kameyama, A. \& Nishikubo, T. A novel synthesis of polyaddition of Bis(epoxide)s with diphenyl carbonate. Macromolecules 34, 3205 (2001).

10 Kawasaki, S., Yamada, M., Kobori, K., Sakamoto, H., Kondo, Y, Jin, F. \& Takata, T. Preparation of novel alloy composed of fluorene-based polyester and polycarbonate and their properties for the optical uses. J. Appl. Polym. Sci. 111, 461 (2009).
11 Voit, B. New developments in hyperbranched polymers. J. Polym. Sci. Part A: Polym. Chem. 38, 2505 (2000).

$12 \mathrm{Kim}, \mathrm{H}$. M. Hyperbranched polymers 10 years after. J. Polym. Sci. Part A: Polym. Chem. 36, 1685 (1998).

13 Gao, C. \& Yan, D. Hyperbranched polymers: from synthesis to applications. Prog. Polym. Sci. 29, 183 (2004).

14 Parzuchowski, P. G., Jaroch, M., Tryznowski, M. \& Rokicki, G. Synthesis of new glycerolbased hyperbranched polycarbonates. Macromolecules 41, 3859 (2008).

15 Stumpe, K., Eichhorn, K.- J. \& Voit, B. Characterization of thin composite films from hyperbranched polyphenylene and thermolabile hyperbranched polycarbonate. Macromol. Chem. Phys. 209, 1787 (2008).

16 Scheel, A., Komber, H. \& Voit, B. Hyperbranched thermolabile polycarbonates derived from a $\mathrm{A}_{2}+\mathrm{B}_{3}$ monomer system. Macromol. Symp. 210, 101 (2004).

17 Reisch, A., Komber, H. \& Voiy, B. Kinetic analysis of two hyperbranched $A_{2}+B_{3}$ polycondensation reaction by NMR spectroscopy. Macromolecules 40, 6846-6858 (2007).

18 Fan, Z., Lederer, A. \& Voit, B. Synthesis and characterization of $A_{2}+B_{3}$-type hyperbranched aromatic polyesters with phenolic end groups. Polymer 50, 3431 (2009).

19 Bolton, D. H. \& Wooley, K. L. Synthesis and characterization of hyperbranched polycarbonates. Macromolecules 30, 1890 (1997).

20 Bolton, D. H. \& Wooley, K. L. Hyperbranched Aryl polycarbonates derived from $A_{2} B$ monomers versus $A_{2}$ mnomers. J. Polym. Sci. Part A: Polym. Chem. 40, 823 (2002).

21 Maruyama, K., Takazoe, T., Kudo, H. \& Nishikubo, T. Synthesis of photo-curable hyperbranched polycarbonates with terminal methacryloyl groups and their photocuring reaction. Kobunshi Ronbunshu. 66, 36 (2009).

22 Nagai, A., Sato, D., Ishikawa, J., Ochiai, B., Kudo, H. \& Endo, T. A facile synthesis of Ncaroxyanhydrides and poly $(\alpha$-amino acid) using di-tert-butyltricarbonate. Macromolecules 37, 2332 (2004)

23 Dean, C. S., Tarbell, D. S. \& Friederang, A. W. Synthesis and kinetics of decomposition of di-tert-butyl tricarbonate, di-tert-butyl dithioltricarbonate, and the related dicarbonates. J. Org. Chem. 35, 3393 (1970)

24 Yamamoto, Y., Tarbell, D. S., Fehlner, J. R. \& Pope, B. M. Reactions of tert-Butyl trimethylsilyl carbonate and of bistrialkylsilyl carbonates with amino acids. Carbon-13 chemical shifts in carbonates and Silyl carbonate derivatives. J. Org. Chem. 38, 2521 (1973).

25 Ogura, T. \& Ueda, M. Photosensitive polybenzoxazole based on a poly(o-hydroxy amide), a dissolution inhibitor, and a photoacid generator. J. Polym. Sci. Part A: Polym. Chem. 45, 661 (2007)

26 Hawker, C. J., Lee, R. \& Fréchet, J. M. J. One-step synthesis of hyperbranched dendritic polyesters. J. Am. Chem. Soc. 113, 4583 (1991). 